\title{
INTEGRASI AL-QUR'AN DENGAN SUNNAH DALAM MEMBANGUN METODE PENEMUAN HUKUM
}

\author{
Ahmad Mukhlisin \\ Dosen Tetap Universitas Nahdlatul Ulama Lampung \\ J1. Hanafiah Lintas Timur, Mataram Marga Kec. Sukadana Lampung Timur \\ Email: ahmad-mukhlisin@yahoo.com
}

\begin{abstract}
Abstrak: al-Qur'an merupakan masdar dari kata kerja "qara'a" yang berarti bacaan atau yang ditulis. Sedangkan secara terminologi, al-Qur'an didefinisikan oleh Zakaria al-Birri, "Kalamullah yang diturunkan kepada Rasul-Nya Muhammad dengan lafadz bahasa Arab, dinukil secara mutawatir dan tertulis dalam lembaran-lembaran mushafal, sedangkan sunnah adalah segala perkataan, perbuatan yang disandarkan kepada nabi Muhammad saw., al-Qur'an dan sunnah dilihat dari segi kehujjahannya, keduanya merupakan sumber dalam melakukan istinbath (penemuan hukum) atau ijtihad. Istinbath artinya adalah mengeluarkan hukum dari dalil-dalinya. Jalan istinbath ini memberikan kaidah-kaidah yang bertalian dengan pengeluaran hukum dari dalil.

Metode penemuan hukum haruslah dipahami oleh seorang mujtahid dalam rangka mengembangkan pemikiran hukum dalam Islam secara umum dan menjawab persoalan-persoalan hukum kontemporer yang kasusnya tidak diatur secara eksplisit oleh al-Quran dan hadis. Ijtihad dalam mengembangkan pemikiran hukum kontemporer terbagi menjadi tiga, yaitu ijtihad bayani, qiyasi, dan istishlabi.

Kata konci; al-qur'an, al-sunnah, Ijtihad, bayani, qiyasi, dan istishlabi
\end{abstract}

\section{A. Pendahuluan}

Al-Qur'an dan sunnah merupakan mashadir al-tasyri' (sumber hukum) yang muttafaq alaiba (disepakati para ulama ushul). Keduanya tidak bisa dipisahkan satu dengan yang lainnya, dan hal itu tampak dalam penerapan hukum alQur'an dalam kehidupan.

Berdasarkan pernyataan dari abdul Wahhab Khalaf bahwa kedekatan alQur'an dengan sunnah tak satu pun yang mengingkarinya. Dan hal tersebut dapat dilihat dari fungsi sunnah terhadap al-Qur'an:

Pertama, sebagai penguat dan penegas hukum-hukum yang terkandung dalam al-Qur'an, seperti keduanya menegaskan kewajiban shalat, puasa, zakat, haji dan seterusnya. Sebagaimana keduanya melarang perbuatan syirik, durhaka kepada orang tua, membunuh dan seterusnya.

Kedua, sebagai penjelas dan perinci pelaksanaan hukum dalam al-Qur'an, yang disebut di dalamnya secara global. Seperti memberi batasan nash yang muthlaq, mengkhususkan nash yang umum dan lain sebagainya.

Ketiga, berfungsi menetapkan ketentuan hukum yang tidak terdapat dalam al-Qur'an, seperti larangan menikahi seorang perempuan dan bibinya sekaligus, yang belum diharamkan dalam al-Qur'an. ${ }^{1}$ Oleh karena itu Imam Syafi'i menyebutkan

1 Abdul Wahhab Khallaf, Ilm Ushul alFiqh, (Kairo: Dar al-Hadis, 2002), h. 43-44. 
dalam kitabnya "al-risalab"2, bahwa tanpa sunnah, maka al-Qur'an tidak dapat dimengerti.

Dari segi kehujjahannya, keduanya merupakan sumber dalam melakukan istinbath (penemuan hukum) atau ijtihad. Istinbath artinya adalah mengeluarkan hukum dari dalil-dalinya. Jalan istinbath ini memberikan kaidahkaidah yang bertalian dengan pengeluaran hukum dari dalil.

Imam al-Ghazali dalam kitabnya "alMustashfa", memasukan dalam bab III dengan judul "Thuruq al-istitsmar". Jika dilihat tujuan mempelajari ushul fiqh maka hal yang paling penting dalam mempelajari ilmu tersebut adalah agar dapat mengetahui dan mempraktekkan kaidah-kaidah atau cara mengeluarkan hukum dari dalilnya.

Dengan demikian metode penemuan hukum merupakan thuruq alistinbath yaitu cara-cara yang ditempuh seorang mujtahid dalam mengeluarkan hukum dari dalilnya, baik dengan menggunakan kaidah-kaidah bahasa (linguistik) maupun dengan menggunakan kaidah-kaidah ushuliyah lainnya.

Metode penemuan hukum haruslah dipahami oleh seorang mujtahid dalam rangka mengembangkan pemikiran hukum dalam Islam secara umum dan menjawab persoalan-persoalan hukum kontemporer yang kasusnya tidak diatur secara eksplisit oleh al-Quran dan hadis.

Oleh karenanya dengan berbagai macam metode yang diterapkan diharapakan akan dapat menemukan hukum-hukum dalam memecahkan

2 Muhammad bin Idris al-Syafi'i, alRisalah, (Beirut: Dar al-Kutub al-Ilmiah, 2014), h. 115.

3 Muhammad bin Muhammad alGhazali, al-Mushtashfa, Jilid II, (Kairo: Dar al-Hadis, 2011), h. 461. berbagai persoalan yang muncul, makalah ini akan mencoba menguraikan metode penemuan hukum dengan cara ijtihad bayani, qiyasi dan isishlabi.

\section{B. Pembahasan}

1. Al-Qur'an dan Sunnah sebagai Sumber Hukum

a. Pengertian al-Qur'an dan dalalabnya

Secara etimologis al-Qur'an merupakan masdar dari kata kerja "qara'a" yang berarti bacaan atau yang ditulis. Sedangkan secara terminologi, al-Qur'an didefinisikan oleh Zakaria al-Birri, "Kalamullah yang diturunkan kepada Rasul-Nya Muhammad dengan lafadz bahasa Arab, dinukil secara mutawatir dan tertulis dalam lembaran-lembaran mushaf."

Kehujjahan al-Qur'an terletak pada kebenaran dan kepastian isinya yang sedikitpun tiada keraguan di dalamnya. ${ }^{5}$ Oleh karena itu hukumhukum yang terkandung dalam alQur'an merupakan aturan-aturan yang wajib diikuti oleh manusia sepanjang masa.

Dilihat dar sisi kebenarannya sebagai sumber, maka al-Qur'an adalah merupakan sumber dari segala sumber hukum, karena ia menempati posisi paling awal dari tertib sumber hukum dalam berhujjah.

Yang dimaksud dengan dalalah dalam konteks pemahaman makna atau pengertian dari nash adalah petunjuk yang dapat dijadikan

${ }^{4}$ Zakaria al-Birri, Mashadir al-Abkam alIslamiyah, (Kairo: Dar al-Ittihad al-Arabi, 1975), h. 16.

5 Abdul Wahhab Khallaf, Ilmu Ushul Fiqh..., h. 24. 
pegangan untuk membawa kepada pengertian yang dikehendakinya.

Dalam kajian ushul fiqh, untuk memahami nash, apakah pengertian yang ditunjukan oleh unsur-unsur lafadznya jelas atau tidak, ulama ushul menggunakan pendekatan yang dikenal dengan istilah qath'i atau zhanni. Terma ini digunakan untuk nash-nash yang lafadznya menunjukan kepada pengertian atau makna yang sudah jelas atau tegas serta tidak mungkin lagi diragukan.

Tentang qath'i, hubungannya dengan nash, ulama ushul membaginya menjadi dua macam; pertama: disebut dengan qath'i alwurud dan kedua disebut dengan qath'i al-dalalah. ${ }^{\top}$

Adapun terma zhanni, adalah nash-nash yang akan dijadikan dalil itu, kepastiannya belum sampai kepada tingkatan qath'i. Sama seperti qath'i, ulama ushul membagi z̧מanni kepada dua macam; zhanni al-wurud ${ }^{8}$ dan ₹hanni al-dalalah. ${ }^{9}$

b. Pengertian Sunnah dan Dalalahnya

Secara literal sunnah berarti cara atau jalan yang terpuji maupun tercela. Menurut ulama ushul,

${ }^{6}$ Menurut Safi Hasan Abu talib, qath'i al-wurud adalah nash-nash yang sampai kepada kita dengan cara mutawatir. Lihat. Safi Hasan Abu talib, Tatbi' al-Syariah alIslamiyah fi al-Bilad al-Arabiyah, (Kairo: Dar al-Nahdhah al-Arabiyah, 1990), h. 62.

${ }^{7}$ Qath'i al-dalalah adalah nash-nash yang lafadznya menunjukan pengertian yang pasti dan jelas.

${ }^{8}$ Zhanni al-wurud adalah nash-nash yang masih diperdebatkan tentang keberadaannya karena dinukil dengan cara yang tidak mutawatir.

${ }^{9}$ Zhanni al-dalalah adalah nash-nash yang pengertiannya tidak tegas yang masih mungkin dita'wilkan atau mengandung pengertian lain dari arti literalnya. Lihat. Romli SA, Muqaranah Mazabib fi al-Ushul, (Jakarta: Gaya Media Pratama, 1999), h. 62. sunnah adalah "apa yang diriwayatkan dari Nabi Muhammad SAW, baik dalam bentuk ucapan, perbuatan maupun pengakuan dan sifat Nabi."

Dilihat dari sisi sunnah sebagai dasar penetapan hukum, maka di antaranya ada yang qath'i al-wurud dan zhanni al-wurud. Abdul Karim Zaidan menyebut bahwa yang dimaksud qath'i al-wurud adalah hadis-hadis mutawatir, karena hadishadis mutawatir tidak diragukan kebenaran, bahwa ia datang dari Nabi SAW. ${ }^{10}$

Sedangkan zhanni al-wurud adalah hadis-hadis masyhur dan ahad. Karena keduanya dilihat dari segi penukilannya dari Nabi tidak mencapai tingkat mutawatir. Oleh karena itu dari segi wurudnya, hadis masyhur dan ahad adalah ₹̧hanni.

Kemudian sunnah dari sisi dalalahnya, yaitu petunjuk yang dapat dipahami terhadap makna dapat dibedakan kepada qath'i aldalalah dan zhanni al-dalalah. Sunnah yang dalalabnya qath'i adalah hadishadis yang pengertian yang ditunjukannya mengandung makna yang pasti dan jelas. Sedangkan zhanni al-dalalah adalah hadis-hadis yang makna lafadznya tidak menunjukan kepada makna yang tegas, karena masih dimungkinkan diartikan dengan pengertian yang lain. $^{11}$

c. Kedudukan Hadits terhadap AlQur'an

Al-Qur'an merupakan kitab suci yang menjadi pedoman pokok seluruh umat islam disemua penjuru

${ }^{10}$ Abdul Karim Zaidan, al-Wajiz fi Ushul al-Fiqh, (Bagdad: al-Dar al-Arabiyah li alTiba'ah, 1977), h. 177.

11 Romli SA, Muqaranah Mazabib fi alUshul, (Jakarta: Gaya Media Pratama, 1999), h. 77 . 
dunia dalam hal syari'at agama. Sebagaimana Al-Qur'an, Hadits pun mempunyai kedudukan tinggi dalam perannya menjadi landasan dasar hukum syariat, yakni menempati kedudukan yang kedua setelah $\mathrm{Al}$ Qur'an. ${ }^{12}$

Hal ini didasarkan pada Firman Allah Surat An Nisa' ayat 59:

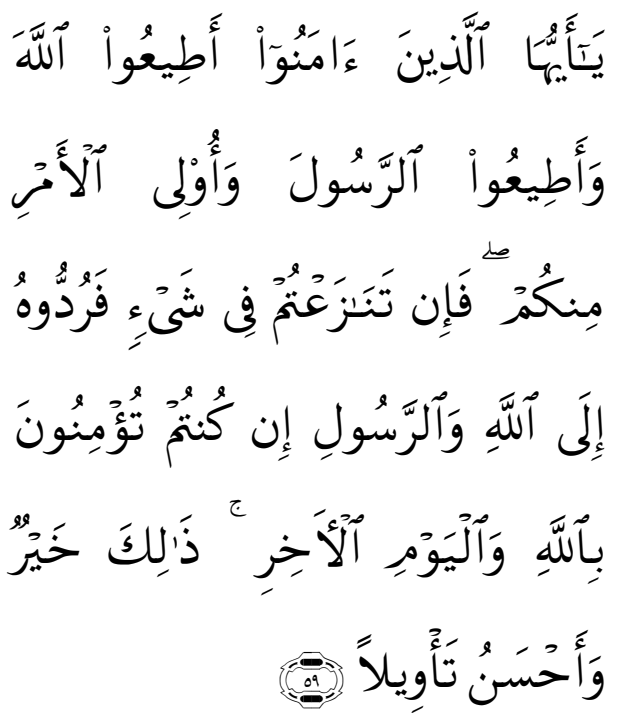

Hai orang-orang yang beriman, taatilah Allah dan taatilah Rasul (nya), dan ulil amri di antara kamu. Kemudian jika kamu berlainan pendapat tentang sesuatu, Maka kembalikanlah ia kepada Allah (Al Quran) dan Rasul (sunnahnya), jika kamu benar-benar beriman kepada Allah dan hari kemudian. yang demikian itu lebih utama (bagimu) dan lebih baik akibatnya.

Menurut Muhammad Ajjaj al Khotib mengatakan bahwa kedudukan hadits sejajar dengan AlQur'an, dengan dalih keberadaannya merupakan wahyu dan hukumnya wajib untuk diamalkan isinya, juga karena fungsi hadits adalah sebagai penjelas dari isi al-Qur'an sendiri, maka tidak mungkin mmemahami AL-

12 M. Nur Ichwan, Studi Ilomu Hadits (Semarang : Rasail Media) h. 36
Qur'an tanpa adanya Hadits disampingnya. ${ }^{13}$

d. Fungsi Hadits terhadap AlQur'an

Sebagaimana yang telah dijelaskan pada pembahsan yang lalu, bahwa Al-Qur'an merupakan dasar syariat yang bersifat sangat global sekali, sehingga bila hanya monoton menggunakan dasar AlQur'an saja tanpa adanya penjelasan lebih lanjut maka akan banyak sekali masalah yang tidak terselesaikan ataupun menimbulkan kebingungan yang tak mungkin terpecahkan. Semisal pada kenyataan praktik sholat, dalam AlQur'an hanya tertulis perintah untuk mendirikan sholat, tanpa ada penjelasan berapa kali solat dilaksanakan dalam sehari semalam, lebih-lebih apa saja syarat dan rukun sholat, dan lain sebagainya. ;orang yang hanya berpegang pada AlQur'an saja tidak mungkin bisa mengerjakan sholat, bagaimana praktik sholat, apa saja yang harus dilakukan dalam sholat, apa saja yang harus dijauhi ketika melakukan sholat, dan lain-lain. Maka, disinilah urgensitas hadits, yang mempunyai peran penting sebagai penafsir dan penjelas dari keglobalan isi AlQur'an, sehingga manusia dapat mempelajari dan memahami islam secara utuh.

Lebih spesifik lagi, setidaknya ada 4 fungsi yang menjadi peran

13 Dr. Muhammad Ajjaj al Khotib, Ushul al Hadits, cet. 4 (Jakarta : Gema Media Pramata, 2007) h. 35 
penting hadits terhadap Al-Qur'an, yaitu :

1). Sebagai Penguat kandungan Hukum Al-Qur'an

Istilah ini lebih dikenal dengan Bayan taqriry atau dengan kata lain bayan ta'qidy atau bayan al itsbat, yaitu penjelasan hadits terhadap Al-Qur'an yang bersifat menguatkan atau mengukuhkan. Ini terjadia apabila isi kandungan hadits sama dengan yang ada pada ayat $\mathrm{Al}$ Qur'an, sehingga hadits seakan hanya berperan sebagai penguat atau pengokoh atas hukum yang terkandung dalam Al-Qur'an. Contoh dalam surat Al-Maidah ayat 6, Allah berfirman :
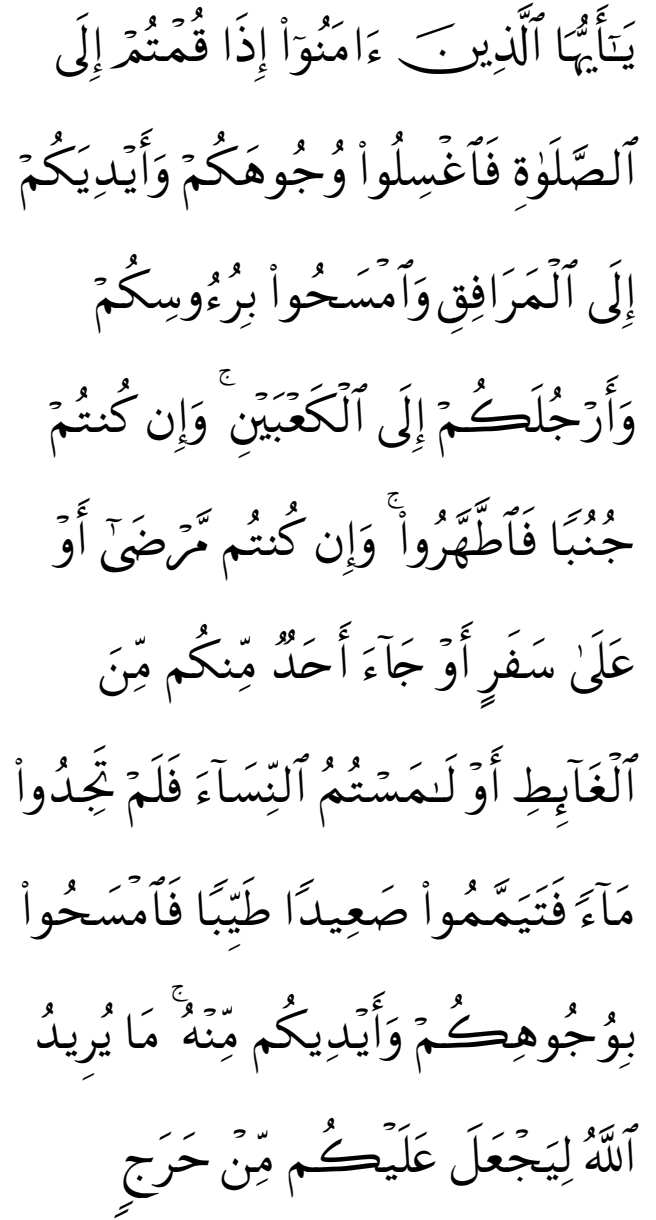

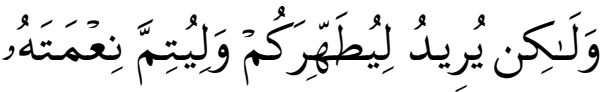

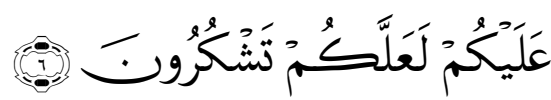

Hai orang-orang yang beriman, apabila kamu hendak mengerjakan shalat, Maka basuhlah mukamu dan tanganmu sampai dengan siku, dan sapulah kepalamu dan (basuh) kakimu sampai dengan kedua mata kaki, dan jika kamu junub Maka mandilah, dan jika kamu sakit atau dalam perjalanan atau kembali dari tempat buang air (kakus) atau menyentuh perempuan, lalu kamu tidak memperoleh air, Maka bertayammumlah dengan tanah yang baik (bersih); sapulah mukamu dan tanganmu dengan tanah itu. Allah tidak hendak menyulitkan kamu, tetapi dia hendak membersihkan kamu dan menyempurnakan nikmat-Nya bagimu, supaya kamu bersyukur.

Kandungan ayat tersebut senada dengan hadits nabi yang mengatakan

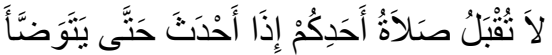

Tidak diterima sholat salah satu dianytara kalian yang masih mempunyai hadats (kecil) sehingga berwudlu. ${ }^{14}$

Pada kasus seperti ini, maka fungsi hadits hanya mengukuhkan hukum yang terkandung dalam ayat tersebut, Karena antara keduannya mempunyai isi yang sama.

${ }^{14}$ Hadits Shohih Muslim, juz 1 h. 130 hadits ke-559 
2). Sebagai Penjelas Kandunag Ayat Al-Qur'an

a). Menjelaskan keglobalan ayat Al-Qur'an

Yaitu hadits memberi penjelasan lebih terperinci mengenai beberapa aspek yang berhubungan dengan ibadah. Mulai dari hukum, tata cara, syarat-syarat, hingga waktu dan ketentuan-ketentuannya. Karena didalam Al-Qur'an belum ada keterangan mengenai kesemua itu, sebagian baru dapat dimengerti melalui hadits nabi. Sebagai contoh : Al-Qur'an hanya memerintahkan untuk mengerjakan sholat :

dan dirikanlah shalat, tunaikanlah zakat dan ruku'lah beserta orangorang yang ruku'. ${ }^{15}$

Pada ayat ini masih sangat global, ayat ini hanya memerintahkan untuk mendirikan sholat, sedangkan untuk tatacara, rukun-rukunnya, hal apa saja yang harus ditinggalkan sama sekali belum ada dalam Al-Qur'an, maka diperjelas dengan perkataan Nabi:

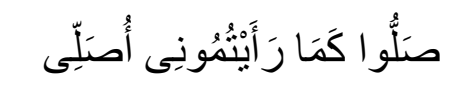

Sholatlah kalian semua sebagaimana aku sholat.

Maka dengan penjelasan Nabi dan prektek langsung beliau terhadap pekerjaan sholat, jelaslah sudah bagaimana tata cara melakukan sholat, apa saja

${ }^{15}$ Q.S. Al Baqoroh ayat 43. yang harus dipenuhi, apa yang harus dijauhi, dan lain sebagainya.

b). Memberi batasan atas kemuthlakan ayat Al-Qur'an

Sebagai contoh Firman Allah dalam Al-Qur'an mengatakan : laki-laki yang mencuri dan perempuan yang mencuri, potonglah tangan keduanya (sebagai) pembalasan bagi apa yang mereka kerjakan dan sebagai siksaan dari Allah. dan Allah Maha Perkasa lagi Maha Bijaksana. ${ }^{16}$

Pada ayat ini hanya menjelaskan memotong tangan secara muthlak, belum dijelaskan sampai batas apakah pemotongan tangan tersebut, akhirnya pada hadits nabi memberi batasan, bahwa pemotongan tangan dilakukan sampai batas pergelangan tangan.

c). Menghususkan ayat yang masih umum

Pada surat Al An'am ayat 82, dijelaskan bahwa orang yang tidak mencampur adukkan imannya dengan kedzaliman, maka ia akan mendapatkan keamanan.

orang-orang yang beriman dan tidak mencampuradukkan iman mereka dengan kezaliman (syirik), mereka Itulah yang mendapat keamanan dan mereka itu adalah orang-orang yang mendapat petunjuk.

Kata "kedzaliman" pada ayat ini masih bersifat umum, sehingga masih membutuhkan penjelasan. Kemudian hadits nabi datang dengan menghususkan bahwa yang

${ }^{16}$ Q.S. Al Maidah ayat 38 
dimaksud dzalim disini adalah kemusyrikan.

لما نزلت ( الذين آدنوا ولم يلبسوا إيمانهم بظلم ) ـ شق ذلك على المسلمين

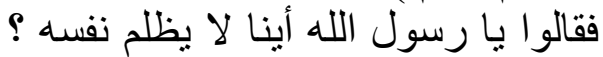

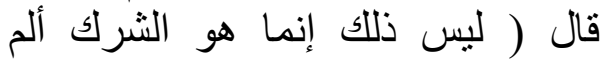

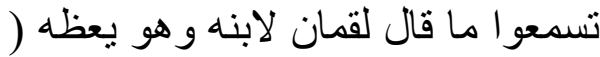

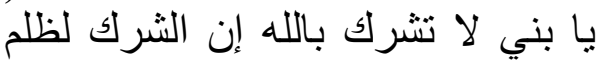
(عظيم )

d). Menjelaskan yang masih samar (belum jelas).

Seperti hadits nabi yang menjelaskan maksud ayat Al-Qur'an Hai orang-orang yang beriman, diwajibkan atas kamu qishaash berkenaan dengan orang-orang yang dibunuh; orang merdeka dengan orang merdeka, hamba dengan hamba, dan wanita dengan wanita. Maka Barangsiapa yang mendapat suatu pema'afan dari saudaranya, hendaklah (yang mema'afkan) mengikuti dengan cara yang baik, dan hendaklah (yang diberi ma'af) membayar (diat) kepada yang memberi ma'af dengan cara yang baik (pula). yang demikian itu adalah suatu keringanan dari Tuhan kamu dan suatu rahmat. Barangsiapa yang melampaui batas sesudah itu, Maka baginya siksa yang sangat pedih. ${ }^{17}$

17 Qishaash ialah mengambil pembalasan yang sama. qishaash itu tidak dilakukan, bila yang membunuh mendapat kema'afan dari ahli waris yang terbunuh Yaitu dengan membayar diat (ganti rugi) yang wajar. pembayaran diat diminta dengan baik, umpamanya dengan tidak mendesak yang membunuh, dan yang membunuh hendaklah membayarnya dengan baik, umpamanya tidak menangguh-nangguhkannya. bila ahli waris si korban sesudah Tuhan menjelaskan
Ternyata yang dimaksudkan dengan benang hitam adalah malam hari, sedangkan benang putih adalah siang hari.

لما نزلت \} حتى يتبين لكم الخيط

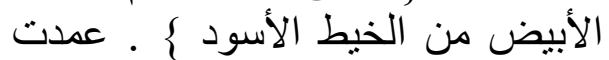
إلى عقال أسود ورإلى عقال أبيض فجعلتهما تحت وسادتي فجعلت أنظر في الليل فلا يستبين لي فغدوت على في

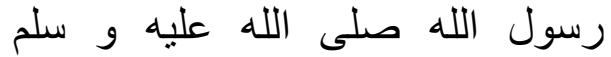
فذكرت له ذللك فقال ( إنما ذلك سواد



3). Sebagai Tambahan Hukum Syariat Islam.

Dalam hal ini, para ulama' masih berbeda pendapat. Perbedaan pendapat ini tidak mempertentangkan kedudukan dan keabsahan hadits sebagai hukum tambahan terhadap hukumyang telah ada dalam Al-Qur'an, melainkan pada cara analisa dan menetapkan hukum sebagai tambahan, dan mencari metode untuk menetapkan hukum sebagai tambahan itu. ${ }^{18}$

4). Sebagai perombak hukum yang ada pada Al-Qur'an.

Hal ini masyhur dengan sebutan me-Nasah hukum, yakni keberadaan Hadits sebagai perombak hukum yang sekiranya

2. Membangun Penemuan Hukum dengan Menggunakan Metode Ijtihad

hukum-hukum ini, membunuh yang bukan si pembunuh, atau membunuh si pembunuh setelah menerima diat, Maka terhadapnya di dunia diambil qishaash dan di akhirat Dia mendapat siksa yang pedih.

18 Muhamad Nor Ikhwan, Studi ilmu Hadits (cet 1; Semarang: Rasail : 2007) h. 44 


\section{a. Definisi Ijtihad}

Ada banyak nash dari al-Qur'an dan hadis yang menjelaskan tentang penggalian hukum Islam melalui jalan ijtihad, firman Allah SWT dalam surat an-Nisâ' ayat 59:

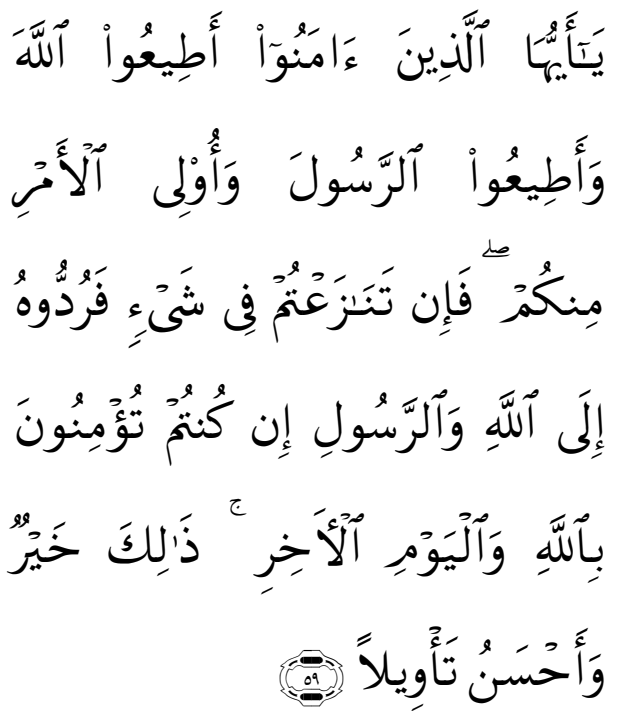

Hai orang-orang yang beriman, taatilah Allah dan taatilah Rasul (nya), dan ulil amri di antara kamu. Kemudian jika kamu berlainan pendapat tentang sesuatu, Maka kembalikanlah ia kepada Allah (Al Quran) dan Rasul (sunnahnya), jika kamu benar-benar beriman kepada Allah dan hari kemudian. yang demikian itu lebih utama (bagimu) dan lebih baik akibatnya.

Ibnu Âsyûr menyinggung makna "berlainan pendapat tentang sesuatu, maka kembalikanlah ia kepada Allah (al-Qur'an) dan Rasul (sunnahnya)", adalah perbedaan ulama dalam persoalan hukum, yang digali melalui jalan ijtihad dan mengkaji dalil-dalil syar'i. ${ }^{19}$

Landasan ini diperkuat pula dengan sabda Nabi SAW kepada Muadz bin Jabal ketika beliau

${ }^{19}$ Muhammad al-Tahir ibn 'Âsyûr, alTahrîr wa al-Tanwîr, Jilid IV, (Beirut: Muassasah al-Tarikh, 2000), h. 168. mengutusnya menjadi Gubernur di Yaman:

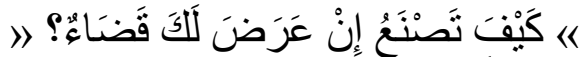

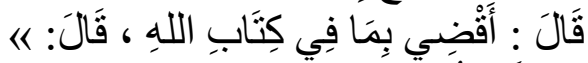

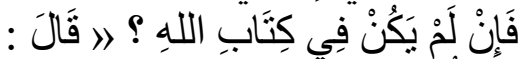

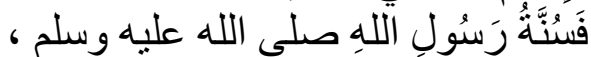

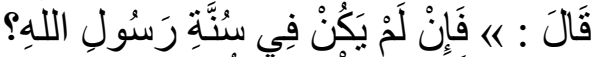

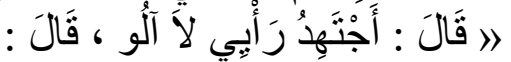

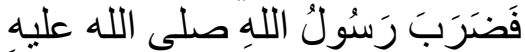

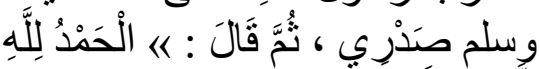

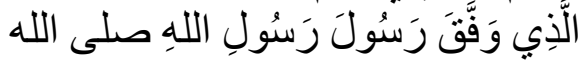

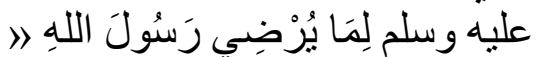

$$
\begin{aligned}
& \text { أخرجه أبو داود20 والترمذيهي } 21
\end{aligned}
$$

"Ya mu'adz bagaimana cara engkau memutuskan perkara yang disampaikan seseorang kepadamu?." Muadz menjawab, "Saya akan memutuskannya menurut yang tersebut dalam kitâbullâh."Nabi SAW bertanya lagi, "Sekiranya engkau tak menemukan hal itu dalam kitâbullâh?." Mu'âdz menjawab, "Saya akan memutuskannya menurut sunnah Rasul-Nya." Lalu Nabi SAW bertanya lagi, "Kalau hal itu tidak ditemukan juga dalam keduanya, yakni Kitâbullâh dan sunnah Rasul, apa yang akan engkau lakukan?." Lalu Mu'âdz menjawab,"Jika tidak terdapat dalam keduanya saya akan berijtihâd tanpa ragu sedikitpun. "Mendengar jawaban itu, Nabi Muhammad SAW lalu meletakkan kedua tangannya ke dada Mu'âdz seraya bersabda, "Segala puji bagi Allah yang telah memberi taufiq kepada utusan

${ }^{20}$ Sulaiman bin al-Asy'as al-Sajistani alAzdî, Sunan Abi Daud, (Beirut: Dar Ibni Hazm, 1998), h. 553.

${ }^{21}$ Muhammad bin 'Isa bin Sûrah alTirmidzi, Sunan al-Tirmidzi, (Kairo: Dar alFajr, 2011), h. 359. 
Rasulullah, sehingga menyenangkan hati Rasul-Nya."

Ijtihad secara etimologi sebagaimana disebutkan Ibnu Manzûr berarti mengeluarkan segenap kemampuan untuk menggapai sesuatu. Al-Fakhr al-Râzî mengatakan bahwa ijtihad sebagai ungkapan bersungguh-sungguh menggunakan tenaga -baik fisik maupun pikiran- untuk membahasakan mengangkat sesuatu yang berat penuh dengan kesulitan. Oleh karena itu tidak disebut ijtihad jika hanya mengangkat hal-hal yang ringan seperti mengangkat sebiji kurma. ${ }^{22}$

Secara terminologi ijtihad didefinisikan oleh Abû Zahrah: ${ }^{23}$

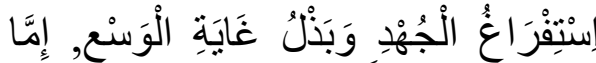

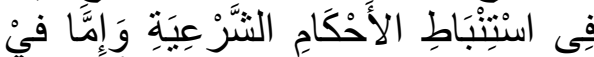

“Usaha mengerabkan seluruh tenaga dan segenap kemampuannya, baik dalam menetapkan bukum-bukum syara' maupun dalam penerapannya".

Berdasarkan pengertian di atas, maka ijtihad terbagi menjadi dua macam, yaitu ijtihad untuk membentuk atau meng-istinbât hukum dari dalilnya dan ijtihad untuk menerapkannya. Model ijtihad pertama khusus untuk para ulama yang mengkhususkan diri untuk meng-istinbât hukum dari dalilnya. Ulama Hanâbilah berpandangan bahwa model ijtihâd ini tidak boleh kosong dari masa ke masa, karena persoalan hukum baru akan terus bermunculan dan harus mendapatkan kepastian hukumnya.Sedangkan model ijtihâd

${ }^{22}$ Fakhruddîn Muhammad bin Umar alRazî, al-Mahsûl fî̀ Ilmi Usûl al-Fiqh, Jilid II, (Beirût: Muassasah al-Risâlah, 2012), h. 407.

${ }^{23}$ Muhammad Abû Zahrah, Usûl al-Fiqh, (Kairo: Dar al-Fikr al-Arabi, 2012), h. 341. yang kedua, yaitu ijtibâd dalam penerapan hukum, akan selalu ada di setiap masa selama umat Islam mengamalkan ajaran agama mereka karena mujtahid semacam ini adalah untuk menerapkan hukum Islam termasuk hasil-hasil ijtihâd para ulama terdahulu ${ }^{24}$

Imam Syâfi'î (150-204 H), penyusun kitab al-risâlah, ketika menggambarkan kesempurnaan alQur'an menegaskan, "Tidak terjadi suatu peristiwa pun pada seorang pemeluk agama Allah, kecuali dalam kitab Allah terdapat petunjuk tentang hukumnya." Menurut beliau, hukum-hukum yang dikandung dalam al-Qur'an yang bisa menjawab berbagai persoalan itu harus digali dengan kegiatan ijtihad. Oleh karena itu, Allah mewajibkan kepada hamba-Nya untuk berijtihad dalam upaya menimba hukum-hukum dari sumbernya itu, selanjutnya beliau mengatakan bahwa Allah menguji ketaatan seseorang untuk melakukan ijtihad sama halnya dengan seperti Allah menguji ketaatan hamba-Nya dalam hal-hal yang diwajibkan lainnya. ${ }^{25}$

Abu Thayyib Abadi memaknai kata ijtihâd sebagai mencurahkan segenap kemampuan untuk menemukan hukum suatu perkara dengan menganalogikan perkara tersebut kepada kitab al-Qur'an dan Sunnah. ${ }^{26}$

Para sahabat di zaman nubuwah telah berijtihad dalam berbagai

\footnotetext{
${ }^{24}$ Satria Effendi, Ushul Fiqh, (Jakarta: Kencana, 2014), h. 246.

${ }^{25}$ Satria Effendi, Ushul Figh..., h. 249.

${ }^{26} \mathrm{Abu}$ Thayyib Syams al-Haq al-'Azim Abadî, 'Aun al-Ma'bûd Syarb Sunan Ab̂̀ Dand, Jilid IX, (Beirût: Dar al-Kutub alIlmiyyah, 1998), h. 368.
} 
persoalan hukum dan hal itu dibenarkan Nabi SAW.Ketika Nabi SAW memerintahkan para sahabatnya untuk bertolak menuju perkampungan Banî Quraizah, dan melarang mereka melaksanakan shalat Ashar kecuali setelah sampai di perkampungan Yahudi tersebut.

Ibnu al-Qayyim ${ }^{27}$ menyebutkan ijtihad sahabat memahami nash tersebut. Sebagian sahabat menunda shalat Ashar, mereka tidak melakukannya kecuali di perkampungan Banî Quraizah karena mengikuti perintah Nabi SAW sekaligus meninggalkan ta'wil-an yang bertentangan dengan zhahir hadis tersebut (tekstual). Yang lain memahami nash secara kontekstual, maka mereka melakukan shalat Ashar di tengah perjalanan, pada waktunya, karena mereka khawatir tidak mendapati waktu shalat Ashar setelah sampai di perkampungan Yahudi tersebut. Dan kelompok ini sebut dengan abl al-qiyâs. ${ }^{28}$

Muhammad Ahmad Râsyid menyatakan bahwa seorang faqîh

\footnotetext{
${ }^{27}$ Syamsuddîn Abû 'Abdillah Muhammad bin Abû Bakar bin Ayyûb bin Su'ud al-Zar'i al-Dimasyqî, dan dikenal dengan sebutan Ibnu al-Qayyim.Beliau lahir di Damaskus, Sûriah pada tanggal 4 Februari 1292, dan meninggal pada 23 September 1350) adalah seorang Imam Sunni, cendekiawan, dan ahli fiqh yang hidup pada abad ke-13.Ia bermazhab Hanbalî. Di samping itu juga seorang ahli tafsir, hadis, penghafal al-Qur'an, nahwu, ushûl, ilmu kalam, sekaligus seorang mujtahid, (Muhammad Usman al-Khasyat, al-Fawaid Ibnul Qayyim, Riyadh: Dar alKhani, 1993), h. 7-9.

${ }^{28}$ Syamsudîn Abû Abdullah Muhammad bin Abû Bakar, Ibn Qayyim al-Jauziyah, Zad al-Ma'ad, Jilid III, (Beirût: Muassasah al-Risâlah, 1994), h. 130.
}

dapat dikatagorikan berijtihad jika memenuhi empat kriteria: ${ }^{29}$

Pertama, seorang faqih telah bersungguh-sungguh mencurahkan segala kemampuannya untuk menggali ketentuan hukum suatu masalah, sehingga ia merasa sudah tidak mampu lagi mengerahkan kemampuan melebihi batas kemampuannya tersebut.

Kedua, yang mengerahkan kemampuan untuk menggali hukum Islam tersebut adalah seorang faqîh atau mujtahid dan bukan orang yang tidak memiliki kemampuan secara ilmiah dan kompentensi untuk berijtihad.

Ketiga, tenaga dan kemampuan yang dikerahkan bertujuan untuk menggali hukum Islam, bukan dikerahkan untuk menemukan kaidah bahasa, sejalan dengan rasio maupun dasar hukum inderawi.

Keempat, ketetapan hukum yang diperoleh adalah lewat jalur istinbât dari dalîl-dalîl syar'î, bukan dari menghafal berbagai persoalan fiqh atau fatwa-fatwa ulama atau menyadur dari buku-buku figh. ${ }^{30}$

Ibrahim Husein mengidentifikasikan makna ijtihad dengan istinbât. Istinbât barasal dari kata nabâta yaitu air yang mula-mula memancar dari sumber yang digali.Kemudian kata kerja tesebut dijadikan bentuk sulâsî maఇîd (transitif), sehingga menjadi anbata dan istinbata, yang berarti "mengeluarkan air dari sumur". Oleh karena itu menurut bahasa arti istinbât sebagai murâdif (anonim) dari

${ }^{29}$ Muhammad Ahmad Rasyid, Ushûl alIfta' wa al-Ijtihad al-Tathbîqî,, (Swis: Dar alMihrâb, 2004), h. 43.

${ }^{30}$ Muhammad Ahmad Rasyid, Ulûl alIfta' wa al-Ijtihad al-Tathbîqî..., h. 43. 
kata ijtihad yaitu "mengeluarkan sesuatu dari persembunyian ${ }^{.31}$

Ibnu Manzhur menyebutkan dalam kamusnya "lisan al-'arab", bahwa istinbath berasal dari kata 'nabth', yaitu air yang mula-mula memancar dari sumur yang digali, atau mengeluatrkan sesuatu dari persembunyiannya. ${ }^{32}$

Setelah dipakai dalam istilah hukum Islam, arti istinbath adalah upaya mengeluarkan hukum dari sumbernya. Maka istilah ini hampir sama dengan ijtihad. Hanya saja fokus dari istinbath adalah teks suci dari ayat-ayat al-Qur'an dan hadis Nabi. Oleh karena itu pemahaman, penggalian dan perumusan hukum dari kedua sumber tersebut disebut istinbath.

Upaya istinbath tidak akan membuahkan hasil yang memadai, tanpa pendekatan yang tepat. Tentu saja pendekatan ini terkait dengan sumber hukum. Menurut 'Ali Hasaballah, sebagaimana dikutip oleh Nasrun Rusli33,melihat ada dua cara pendekatan yang dikembangkan oleh para pakar dalam melakukan istinbath, yakni melalui kaidah-kaidah kebahasan dan melalui pengenalan maksud syari'at.

Di antara kaidah-kaidah penting yang dapat dijadikan pegangan para ulama ushul dalam berijtihad untuk menetapkan hukum, seperti

${ }^{31}$ Ibrahim Husein, Ijtihad Dalam Sorotan, (Bandung: Mizan, 1991), h. 25.

32 Ibnu Manzhur, Lisan al-Arab, Jilid XIV, (Beirut: Dar Ihya al-Turas al-Arabi, 1999), h. 21.

${ }^{33}$ Nasrun Rusli, Konsep Ijtihad AsySyaukani, Relevansinya bagi Pembaruan Hukum Islam di Indonesia, (Jakarta: Logos Wacana Ilmu, 1997), h. 110-118. dijelaskan Abd al-Hayy Abd al-'All adalah sebagai berikut: ${ }^{34}$

1). Mengetahui madlûl lugawî dan pemahaman bahasa Arab terhadap nash al-Qur'an dan Sunnah.

2). Mengetahui metode Rasulullah SAW dalam menjelaskan hukum-hukum al-Qur'an.

Dengan kâidah lugawiyah, makna dari suatu lafadz, baik dari dalalabnya maupun uslubnya dapat diketahui dan selanjutnya dapat dijadikan pedoman dalam menetapkan hukum..$^{35}$

b. Metode Ijtihad

Menurut Muhammad Salam Madzkûr, berdasarkan penelusuran terhadap ijtihad para sahabat Nabi SAW terdapat tiga model pemikiran hukum (ijtihad), yaitu ijtihad bayani, qiyasi dan istishlabi.

Ijtihad istishlahi, seperti dijelaskan oleh Muhammad Ma'rûf alDawâlibî, merupakan ijtihad dalam bentuk kedua dari dua bentuk ijtihad bi al-ra'yi, yang secara umum ijtihad dibedakan menjadi dua macam: ijtihad bayânî dan ijtihad bi al-ra'yi. Sedangkan ijtihad bi al-ra'yi terbagi menjadi dua jenis: ijtihad qijâsı̂̀ dan ijtihad istisblabi. ${ }^{37}$

Ketiga model ijtihad tersebut dalam telaah Juhaya S. Praja tampaknya dikatagorikan dalam dua metode, yaitu metode naqliyah dan

${ }^{34}$ Abd al-Hayy Abd al-'All, Usûl Figh alIslamî, Alih Bahasa: Muhammad Misbah, Pengantar Ushul Fikih, Jakarta: Pustaka alKautsar, 2014), h. 244-245.

${ }^{35}$ A. Djazuli, Ilmu Fiqh Penggalian, Perkembangan dan Penerapan Hukum Islam..., h. 5 .

${ }^{36}$ Dedi Supriyadi, Sejarah Hukum Islam, (Bandung: Pustaka Setia, 2010), h. 141.

37 Jaih Mubarok, Metodologi Ijtihad Hukum Islam, (Yogyakarta: UII Press, 2002), h 96. 
aqliyah.Pengelompokan metode ini didasarkan pada karakter sumber hukum Islam itu sendiri yang merupakan gabungan antara wahyu Allah dan ijtihad manusia.termasuk dalam metode naqliyah adalah metode bayanî, sedangkan metode aqliyah terdiri dari metode qiyâsî dan istishlahî. Asafri Jaya Bakri menyebut metode qiyâsî̀ dengan penalaran ta'lîlî dan metode istishlabî dinamakan sebagai metode penalaran istishlahî. Dengan demikian metode hukum Islam memiki tiga corak penalaran, yaitu corak penalaran bayanî, penalaran ta'lîli dan penalaran istishlabî. ${ }^{38}$

1). Ijtihad bayan $\hat{\imath}$

Ijtihad bayanî adalah penjelasan ulama terhadap teks al-Qur'an dan Sunnah. ${ }^{39}$ Atau ijtihad yang menjelaskan makna-makna nash yang global, baik karena belum jelas makna lafadz yang dimaksud maupun lafadz tersebut mengandung makna ganda dan persoalan-persoalan lafadz lainnya, seperti lafadz khash, 'am, musytarak, muawwal, zabir, mufassar, mubkam, khafi, musykil, mujmal, mutasyabih, bakikat, majar, sharîh serta analisa masing-masing dilalah-nya.

Al-Dawâlibî merumuskan ijtihad bayanî secara secara definitif, yaitu: ${ }^{40}$

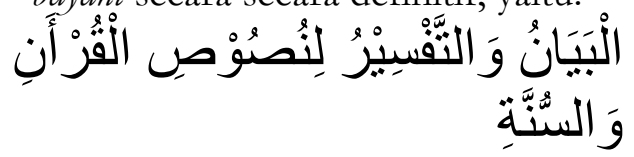

"Penjelasan dan penafsiran terhadap teks al-Qur'an dan Sunnah."

38 Dedi Supriyadi, Sejarah Hukum Islam, (Bandung: Pustaka Setia, 2010), h. 144.

${ }^{39}$ Jaih Mubarok, Metodologi Ijtihad Hukum Islam..., h. 11.

${ }^{40}$ Muhammad Ma'rûf al-Dawalibî, alMadkhal Ila 'Ilm Ushûl al-Figh, (Damaskus: Jami'ah Damaskus, 1959), h. 75.
Sedangkan Muhammad Salam Mażkur menjelaskan bahwa ijtihad bayanî adalah: ${ }^{41}$

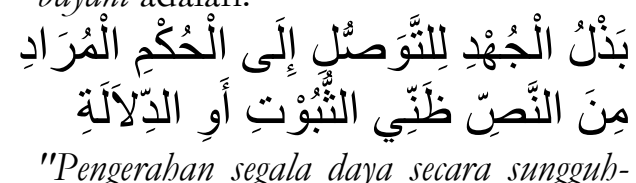
sunggub untuk mencapai bukum yang dikehendaki (Allah) dari teks (nash) yang termasuk zhanni baik wurud maupun dalalabnya."

Dari dua definisi ijtihad bayanî di atas tersimpulkan bahwa ruang lingkup ijtihad bayanî menurut alDawâlibî lebih luas, di mana ia mencakup seluruh teks al-Qur'an dan Sunnah, sedangkan Muhammad Salam Mażkur membatasinya dalam ruang lingkup teks al-Qur'an dan Sunnah yang zhanni ${ }^{42}$ baik ketetapannya atau penunjukan lafadznya.

Dalam perspektif istinbât hukum Islam, metode penemuan hukum bayanî mencakup pengertian altabayun dan al-tabyinn, yaitu proses mencari kejelasan (al-z̧hubur) dan pengayaan penjelasan (al-iz̧hhar), upaya memahami (al-fahm) dan komunikasi pemahaman (al-ifham),

\footnotetext{
${ }^{41}$ Muhammad Salam Mażkur, Manabij alIjtihad fì al-Islam, (Kuwait: Jami'ah alKuwait, 1974), h. 75.

${ }^{42}$ Zhannî al-dalalah ialah ayat-ayat yang tunjukan maknanya mengandung lebih dari satu makna. Meskipun keberadaan teks (nash) semua ayat-ayat al-Qur'an bersifat pasti, namun dari segi makna yang terkandung di dalam ayat-ayatnya, terdapat banyak makna yang bersifat ₹̧annî (relatif). Hal tersebut dipengaruhi oleh dua faktor; faktor kebahasaan dan rumusan-rumusan syara' yang berkaitan dengan prinsip-prinsip hukum Islam. Lihat. Abd. Rahman Dahlan, Ushul Fiqh, (Jakarta: Amzah, 2010), h. 122.
} 
perolehan makna (al-talaqqî) dan penyampaian makna (al-tabligh). ${ }^{43}$

Dalam perkembangan hukum, bayan̂ิ dapat dipahami sebagai "mengartikan", "menafsirkan" atau "menerjemahkan".Dalam pengertian ini bayanî dapat dipahami sebagai proses mengubah sesuatu dari situasi ketidaktahuan menjadi mengerti, atau usaha mengendalikan diri dari bahasa asing yang maknanya masih gelap ke dalam bahasa kita sendiri yang maknanya lebih jelas atau suatu proses transformasi pemikiran dari yang kurang jelas atau ambigu menuju ke makna yang lebih jelas; bentuk transformasi semacam ini, merupakan hal yang esensial dari pekerjaan seorang mufassir. ${ }^{44}$

Secara filosofis, ijtihad bayanî mempunyai tugas ontologis, yaitu menggambarkan hubungan yang tidak dapat dihindari antara teks dan pembaca, masa lalu dan sekarang yang memungkinkan untuk memahami kejadian yang pertama kali (geniun), sehingga ijtihad bayanî dapat dimaknai sebagai metode interpretasi atas teks-teks hukum atau metode memahami suatu naskah normatif, di mana berhubungan dengan isi (kaidah hukumnya), baik yang tersurat maupun yang tersirat, atau antara yang berbunyi hukum dan semangat hukum. ${ }^{45}$

Contoh ijtihad bayani sebagai berikut:

${ }^{43}$ Jasim Hamidi, Hermeneutika Hukum, Teori Penemuan Hukum Baru dengan Interpretasi Teks, (Yogyakarta: UII Press, 2004), h. 23. h. 20 .

${ }^{44}$ Jasim Hamidi, Hermeneutika Hukum...,

${ }^{45}$ Solihin, Metode Istinbat al-Asqalani, (Metro: STAIN Jurai Siwo, 2014), h. 79. a). Hukum larangan menikahi perempuan disebabkan karena ada hubungan susuan sebagaimana tersebut dalam ayat 23 surat an-Nisa', "Dibaramkan ibu-ibumu yang menyusuimu dan saudara-saudara perempuanmu sepersusuan."

Semua ulama sepakat bahwa hubungan susuan menyebabkan haramnya pernikahan. Namun alQur'an tidak menjelaskan berapa kali susuan yang menyebabkan keharaman tersebut.

Al-Hanafiyah dan al-Malikiyah memandang bahwa berdasarkan kemutlakan al-Qur'an, sekali susuan sudah cukup menjadi keharaman perempuan sepersusuan. Karena menyusui baik banyak atau sedikit, sama saja sebagai sebab keharaman. Sedangkan hadis riwayat Ahmad yang diambil oleh imam Syafi'i, yang mendasari keharaman susuan adalah lima kali susuan, dianggap lemah oleh alHanafiyah dan al-Malikiyah, karena bertentangan dengan kemutlakan al-Qur'an. ${ }^{46}$ Hal ini merupakan contoh ijtihad bayani dalam memecahkan ta'arudb aladillah (dalail-dalil yang tampak bertentangan).

b). Terkait dengan pembagian ghanimah sebagaimana tertera dalam surat al-Anfal ayat 41,

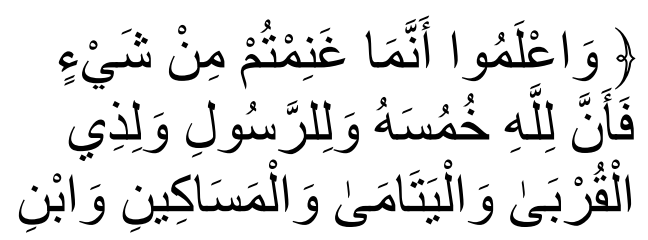

46 Asjmuni Abdurahman, Manbaj Tarjïh Muhammadiyah, (Yogyakarta: Pustaka Pelajar, 2012), h. 140-141. 


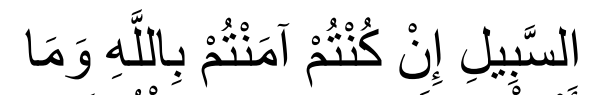

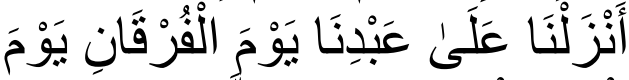

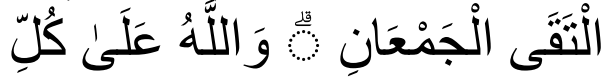

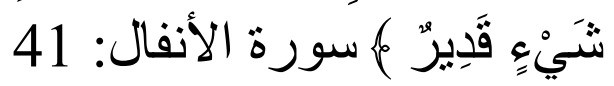

"Ketabuilah, sesunggubnya apa saja yang dapat kamu peroleh sebagai rampasan perang, maka sesunggubnya seperlima untuk Allab, Rasul, kerabat Rasul, anak-anak yatim, orang-orang miskin dan ibnussabil, jikea kamu beriman kepada Allah dan kepada apa yang kami turunkan kepada hamba Kami (Mubammad) di hari Furqaan, yaitu di hari bertemunya dua pasukan. Dan Allah Maha Kuasa atas segala sesuatu."

Di masa khalifah Umar bin Khattab, dengan pertimbangan makin luasnya daerah kekuasaan Islam, yang memerlukan biaya besar untuk pengembangannya, maka Umar menetapkan ijtihadnya, yang akhirnya disetuji oleh sahabat lainnya, bahwa:

Harta bergerak dibagikan seperti dalam nash, yakni seperlima untuk Allah dan rasul-Nya, anak yatim dan fakir miskin.

Sedang harta yang tidak bergerak, dalam hal ini adalah tanah Khaibar, tidak dibagikan kepada pasukan yang turut berperang, mengingat pembiayaan pemerintah cukup menyita dana. Maka pengelolaan tanah Khaibar diserahkan kepada orang-orang Yahudi untuk menggarapnya, dengan tetap membayar jizyah dan kharaj kepada kaum muslimin, sehingga dapat dinikmati oleh para pejuang dan yang turut berperang membela agama. $^{47}$

47 Asjmuni Abdurahman, Manhaj Tarjih Muhammadiyah..., h. 117.
Apa yang dilakukan oleh Umar merupakan bentuk interpretasi terhadap pemahaman ayat 41 dari surat al-Anfal dengan beberapa pemikiran, pertama; pembiayaan yang diperlukan untuk para pejuang yang akan dating. Kedua, akan habisnya tanah tersebut jika dibagikan kepada para peserta perang kala itu, yang tentu hanya mereka yang menguasai tanah dan hanya mereka yang menjadi kaya. Dan hal ini bertentangan dengan firman Allah, “...supaya harta itu jangan hanya beredar di antara orang-orang kaya di antara kamu."48

2). Ijtihad Qiyâsî̀ (bi al-Ra'yi)

Al-ra'yu satu akar kata dengan $r a^{\prime} a$, artinya melihat dengan indera mata nyata, dan bisa pula melihat dalam artian tidak nyata seperti mimpi. Dengan akar kata tersebut para ulama menjelaskan bahwa yang dimaksud dengan al-ra'yu secara bahasa adalah:49

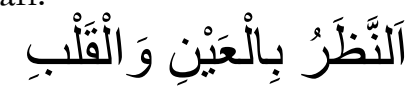

"Melihat (mendalami sesuatu) dengan mata dan hati."

Melihat dengan mata yang dimaksud adalah memperhatikan dengan teliti ( a $^{\prime} y u$ al-baîrab), sedangkan maksud dari melihat dengan hati adalah pengetahuan ilmiah atau pengetahuan berdasarkan keyakinan (ra'yu alilmiyah wa al-i'tiqâdiyah), yang menghasilkan pengetahuan dan pemahaman (al-ilmu wa al-fahm). ${ }^{50}$

Ulama berbeda pendapat dalam menjelaskan pengertian al-ra'yu

48 Al-Qur'an surat al-Hasyr ayat 7.

${ }^{49}$ Abû Bakar Isma'îl Muhammad Miqa, al-Ra'yu wa Asarubu fì Madrasat al-Madinah, (Beirut: Muassasah al-Risâlah, 1985), h. 31.

${ }^{50}$ Jaih Mubarok, Metodologi Ijtihad Hukum Islam..., h. 96. 
secara istilah.Ibnu al-Qayyim berpendapat bahwa yang dimaksud dengan al-ra'yu adalah ijtihad ketika terjadi perbedaan atau bahkan pertentangan (ta'ârud al-amârat). Ibnu al-Qayyim mempertegas pendapatnya dengan mengatakan bahwa ijtihad bi al-ra'yi secara istilah adalah: ${ }^{5}$

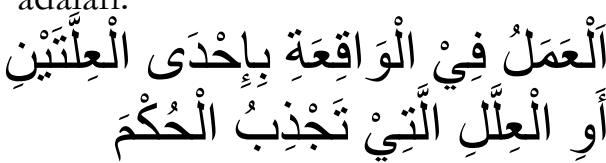

"Penerapan salab satu dari dua atau beberapa illat pada suatu kasus (kejadian) yang mengikat hukum."

Atas dasar arti al-ra'yu tersebut, maka Khallâf menjelaskan bahwa definisi ijtihad bi al-ra'yi adalah: ${ }^{52}$

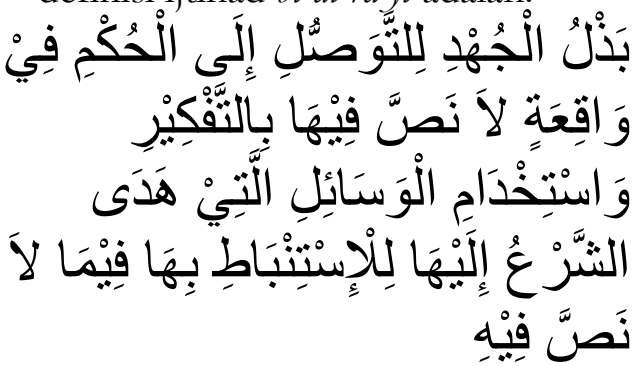

"Kesungguban usaha untuk mendapatkan kepastian (ketentuan) bukum sesuatu yang tidak ada (ketentuan-ketentuannya) dalam naș, dengan berpikir dan menggunakan beberapa media yang ditunjuk oleh syar"at untuk. menentukan bukum sesuatu yang tidak ada nașya."

Muhammad Abû Zahrah memberikan batasan ijtihad bi al-ra'yi dengan lebih rinci: $:^{53}$

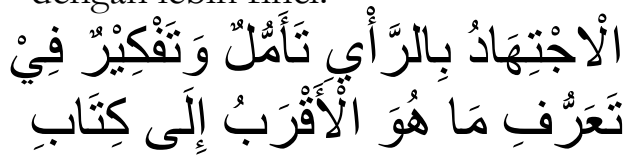

${ }^{51}$ Abû Bakar Isma'îl Muhammad Miqa, al-Ra'yu wa Asarubu ..., h. 39.

${ }_{52}$ Abd Wahhab Khallaf, Mashadir alTasyrì al-Islamî fì ma la nashsha Fîh, (Makkah:)âmi'ah Umm al-Qurâ, tt), h. 17.

${ }^{5}{ }^{3}$ Muhammad Abû Zahra, Mubadharat fi Tarikeh al-Mahazilb al-Fighiyyah, (tt. Jam'iyyah li al-Dirasah al-Fiqhiyyah, tt) h. 17.

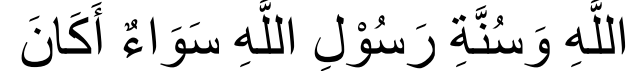

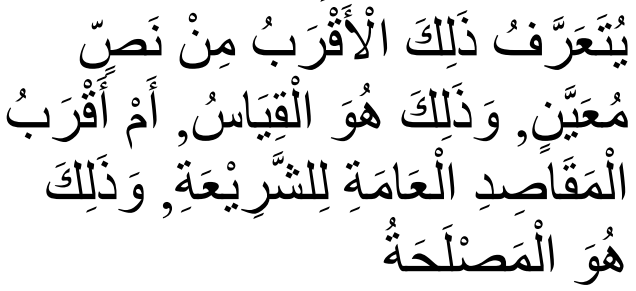

"Dan yang benar, yang dimaksud dengan ijtihad bi al-ra'yi adalah perenungan dan pemikiran dalam upaya untuk. mengetabui sesuatu yang dekat kepada alQur'an dan Sunnab Rasulullah. Sama saja apakah ia lebih dekat kepada alQur'an dan Sunnah secara ayat perayat. Itulah yang disebut qiyâs, atau ia lebih dekat kepada tujuan umum (global) alQur'an dan Sunnab itulah yang disebut dengan al-mașlahat."

Ijtihad qiyâsî, yaitu ijtihad yang berupaya menyeberangkan hukum yang telah ada ketentuan naṣnya pada masalah-masalah baru yang belum ada hukumnya karena ada kesamaan 'illat hukum. Hal ini bisa ditempuh dengan menggunakan qiyâs dan bahkan menggunakan metode istibsân..$^{54}$

Apabila dilacak dasar perumusan dan akar sejarah munculnya istihsân sebagai dalil hukum adalah berawal dari persoalan qiyâs. Qiyâs sebagai salah satu dalil hukum dalam persoalan-persoalan tertentu tidak dapat diterapkan, karena salah satu dari unsur rukunnya yaitu; 'illât tidak memenuhi syarat. Oleh karena itu, harus diselesaikan dengan cara lain yang lebih mendekati tujuan syara, yakni dengan menggali perumusan istihsân sebagai salah satu dalil hukum.

Metode ijtihad ini, untuk menemukan hokum suatu masalah

${ }^{54}$ Dedi Supriyadi, Sejarah Hukum Islam..., h. 141. 
yang tidak ada nash-nya dalam alQur'an dan sunnah, seperti mengisap ganja dan shabu-shabu. Tetapi ada nash lain dari al-Qur'an dan sunnah yang menunjukan keharamannya, seperti keharaman khamr. ${ }^{55}$

Dengan mendasarkan masalah yang dicari hukumnya, seperti mengisap ganja dan shabu-shabu, tidak terdapat hukumnya dalam alQur'an dan sunnah, yang ada kesamaan larangannya adalah keharaman khamr. Menyamakan hokum keharaman ganja dan shabushabu dengan keharaman khamr, disebut oleh al-ushuliyyun sebagai menetapkan hokum berdasarkan qiyas. Dinamakan pula dengan analogi, ilmu logika dan mantiq.

Persoalan bayi tabung, ketika diambilkan dari sperma bukan dari sperma suami, maka bayi tabung tersebut dihukumi hasil dari hubungan illegal atau selingkuh, karena ia lahir dari percampuran sperma bukan suami istri, tetapi dari sperma orang lain yang tidak sah baginya.

Demikian pula larangan pengguguran kandungan setelah sang bayi berusia empat bulan, tanpa alasan syar'i, dianalogikan dengan larangan membunuh hiduphidup bayi perempuan di kalangan bangsa Arab pada masa pra-Islam.

3). Ijtihad istishlahî

Ijtihad istisblabî adalah ijtihad terhadap masalah-masalah yang tidak ditunjukan hukumnya dalam nash secara khusus atau tidak ada nash pada masalah yang serupa alasannya. Inti model ijtihad ini adalah kecenderungan untuk

55 Asjmuni Abdurahman, Manbaj Tarjïh Muhammadiyah..., h. 107. memilih aspek yang mengutamakan kemaslahatan umat. ${ }^{56}$

Ijtihad dipandang dari cakupannya digolongkan atas dua macam, yakni ijtihad mutlaq dan ijtihad juzî. Ijtihad mutlaq dimaksudkan adalah adanya kemampuan yang memungkinkan dari upaya yang dilakukan dalam semua hukum-hukum figh. Sedangkan ijtihad juz $\hat{\imath}$ yang mana kemampuannya hanya terbatas pada sebagian hukum-hukum fiqh saja.

Metode ijtihad dengan corak penalaran istishlahî adalah bagian dari keduanya, dimana kalangan ulama dengan kategori ijtihad mutlaq merumuskan metode terbarunya sedangkan kalangan ulama yang termasuk dalam kategori ijtihad juz $\hat{\imath}$ menekankan maupun mempertegas metode dengan penalaran yang bertumpu pada kemampuan individu serta mempertajam analisisnya dari metode yang dirumuskan pada ulama sebelumnya.

Dianggap sebagai upaya untuk menggali hukum dengan bertumpu pada prinsip-prinsip kemaslahatan yang disimpulkan pada al-Qur'an dan sunnah. Hal ini berarti bahwa kemaslahatan yang dimaksudkan tidak lain adalah kemaslahatan yang secara umum ditunjuk oleh kedua sumber hukum tersebut. Dalam arti lain, kemaslahatan yang ada tidak dapat dikembalikan kepada suatu ayat atau hadis secara langsung, baik melalui proses penalaran yang sifatnya bayani maupun yang sifatnya ta'tic melainkan harus dikembalikan

${ }^{56}$ Dedi Supriyadi, Sejarah Hukum Islam..., h. 141. 
kepada prinsip umum kemaslahatan yang dikandung oleh nash. ${ }^{57}$

Contoh model ijtihad ini adalah Tarjih Muhammadiyah yang memahami penggunaan hijab dalam persidangan persyarikatan yang dihadiri oleh pria dan wanita. Muhammadiyah pada acara Muktamar di Pekajangan, Pekalongan tahun 1960, menetapkan penggunaan tabir pembatas dalam rapat-rapat yang didasarkan pada firman Allah SWT, dalam surat an-Nur ayat 30-31,

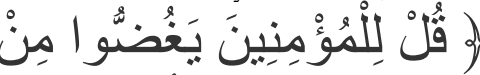

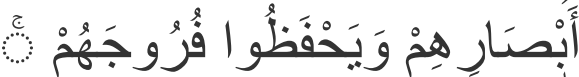

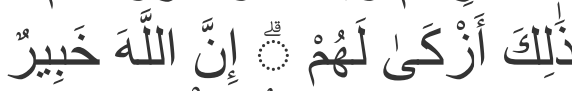

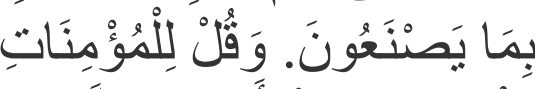

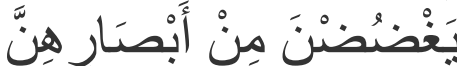

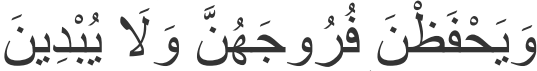



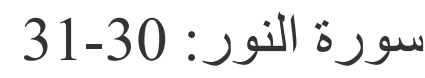

Katakanlah kepada orang laki-laki yang beriman: "Hendaklah mereka menahan pandanganya, dan memelihara kemaluannya; yang demikian itu adalab lebih suci bagi mereka, sesunggubnya Allab Maba Mengetabui apa yang mereka perbuat. Katakanlah kepada wanita yang beriman: "Hendaklab mereka menahan pandangannya, dan kemaluannya, dan janganlah mereka menampakkan perbiasannya, kecuali yang (biasa) nampak dari padanya."

Dalam hal ini Majlis tarjih memahami bahwa perintah untuk tidak terjadi pandang-pandangan yang menimbulkan fitnah di antara

${ }^{57}$ Firman Muhammad Arif, Pengembangan Metode Ijtihad Istislahi dalam Maqasid alSyari'ah, (Jurnal al-Ahkam STAIN Palopo), 1 April 2014. peserta muktamar laki-laki dan perempuan, dengan pemasangan tabir pemisah. ${ }^{58}$

Dengan demikian Majlis Tarjih Muhammadiyah menggunakan kaidah-kaidah yang berlaku di kalangan fuqaha, yakni kaidah yang berbunyi,

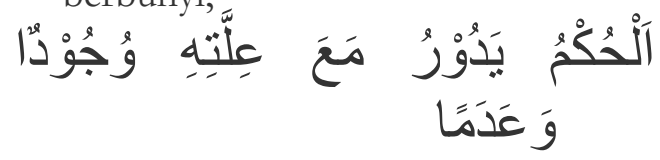

"Hukum itu berdasar pada illat-nya, baik ada atau pun tidaknya.

\section{Kesimpulan}

1. Al-Qur'an dan sunnah merupakan mashadir al-tasyri' (sumber hukum) yang muttafaq alaiha (disepakati para ulama ushul). Keduanya tidak bisa dipisahkan satu dengan yang lainnya, dan hal itu tampak dalam penerapan hukum alQur'an dalam kehidupan. Berdasarkan pernyataan dari abdul Wahhab Khalaf bahwa kedekatan al-Qur'an dengan sunnah tak satu pun yang mengingkarinya. Bahkan imam Syafi'i menyebutkan bahwa tanpa sunnah, maka al-Qur'an sangat sulit dipahami/ dimengerti.

2. Banyak persoalan baru yang muncul di tengah-tengah masyarakat, di mana hukumnya belum disebutkan dalam alQur'an dan sunnah. Para para ulama berijtihad untuk membangun tradisi memecahkan persoalan hukum dalam kehidupan masyarakat.

3. Ijtihad terbagi menjadi tiga, yaitu ijtihad bayani, qiyasi, dan istishlabi.

4. Ijtihad bayani adalah Pengerahan segala daya secara sungguh-

${ }^{58}$ Asjmuni Abdurahman, Manhaj Tarjih Muhammadiyah..., h. 164. 
sungguh untuk mencapai hukum yang dikehendaki (Allah) dari teks (nash) yang termasuk zhanni baik wurud maupun dalalabnya.

5. Ijtihad qiyasi adalah Kesungguhan usaha untuk mendapatkan kepastian (ketentuan) hukum sesuatu yang tidak ada (ketentuan-ketentuannya) dalam naș, dengan berpikir dan menggunakan beberapa media yang ditunjuk oleh syarîat untuk menentukan hukum sesuatu yang tidak ada nash-nya.

6. Sedangkan Ijtihad istishlabi adalah ijtihad terhadap masalah-masalah yang tidak ditunjukan hukumnya dalam nash secara khusus atau tidak ada nash pada masalah yang serupa alasannya. Inti model ijtihad ini adalah kecenderungan untuk memilih aspek yang mengutamakan kemaslahatan umat.

7. Hukum Islam akan terus dinamis, selama ijtihad para ulama tidak beku dan kaku. Walau setiap masa dan keadaan memiliki corak ijtihadnya masing-masing, sesuai dengan keadaan masyarakat dan umatnya. Al-tasyri' al-Islam rahmatan lil 'alamin li kulli makan wa raman.

\section{Daftar Pustaka}

Abadi, Abu Thayyib Syams al-Haq al'Azîm, 'Aun al-Ma'bûd Syarb Sunan Abî Daud, Jilid IX, Beirût: Dar al-Kutub al-Ilmiyyah, 1998.

Abu Daud, Sulaiman bin al-Asy'as alSajistani, Sunan Abi Daud, (Beirut: Dar Ibni Hazm, 1998.

Abu Talib, Safi Hasan, Tatbi' al-Syari'ab al-Islamiyah fi al-Bilad al-Arabiyah,
Kairo : Dar al-Nahdhah alArabiyah, 1990.

Abu Zahrah, Muhammad, Usûl al-Fiqh, Kairo : Dar al-Fikr al-Arabi, 2012.

Al-Birri, Zakaria, Mashadir al-Abkam alIslamiyah, Kairo : Dar al-Ittihad al-Arabi, 1975.

Al-Dawalibi, Muhammad Ma'rûf, alMadkhal Ila 'Ilm Ushûl al-Fiqh, Damaskus : Jami'ah Damaskus, 1959.

Dedi Supriyadi, Sejarah Hukum Islam, Bandung: Pustaka Setia, 2010.

Al-Ghazali, Muhammad bin Muhammad, al-Mushtashfa, Jilid II, Kairo : Dar al-Hadis, 2011.

Husein, Ibrahim, Ijtihad Dalam Sorotan, Bandung: Mizan, 1991.

Ibnu 'Asyur, Muhammad al-Tahir, alTabrî wa al-Tanwir, Jilid IV, Beirut : Muassasah al-Tarikh, 2000.

Ibnu Manzhur, Lisan al-Arab, Jilid XIV, Beirut : Dar Ihya al-Turas alArabi, 1999.

Ibnu al-Qayyim, Syamsudîn Abû Abdullah Muhammad bin Abû Bakar, Zad al-Ma'ad, Jilid III, Beirût: Muassasah al-Risâlah, 1994.

Jaih Mubarok, Metodologi Ijtihad Hukum Islam, Yogyakarta : UII Press, 2002. 
Khallaf, Abdul Wahhab Khallaf, Ilm Usbul al-Fiqh, Kairo : Dar alHadis, 2002.

Rasyid, Muhammad Ahmad, Ushûl alIfta' wa al-Ijtihad al-Tathbîqî, Swis: Dar al-Mihrâb, 2004.

Al-Razi, Fakhruddîn Muhammad bin Umar, al-Mahsûl fî Tlmi Usûl alFiqh, Jilid II, Beirût : Muassasah al-Risâlah, 2012.

Muhammad Salam Mażkur, Manabij alIjtihad fì al-Islam, Kuwait : Jami'ah al-Kuwait, 1974.

Nasrun Rusli, Konsep Ijtihad AsySyaukani, Relevansinya bagi Pembaruan Hukum Islam di Indonesia, Jakarta : Logos Wacana Ilmu, 1997.

Abd al-Hayy Abd al-'All, Usûl Figh alIslamî, Alih Bahasa: Muhammad Misbah, Pengantar Ushul Fikih, (Jakarta: Pustaka al-Kautsar, 2014.

Satria Effendi, Ushul Figh, Jakarta : Kencana, 2014.

Dedi Supriyadi, Sejarah Hukum Islam, (Bandung: Pustaka Setia, 2010

Al-Syafi'i, Muhammad bin Idris, alRisalah, Beirut : Dar al-Kutub alIlmiah, 2014.

At-Tirmidzi, Muhammad bin 'Isa bin Sûrah, Sunan al-Tirmidži, Kairo : Dar al-Fajr, 2011.

Romli SA, Muqaranah Marabib fi alUshul, Jakarta : Gaya Media Pratama, 1999.
Zaidan, Abdul Karim, al-Wajiz fi Ushul al-Figh, Bagdad : al-Dar alArabiyah li al-Tiba'ah, 1977. 